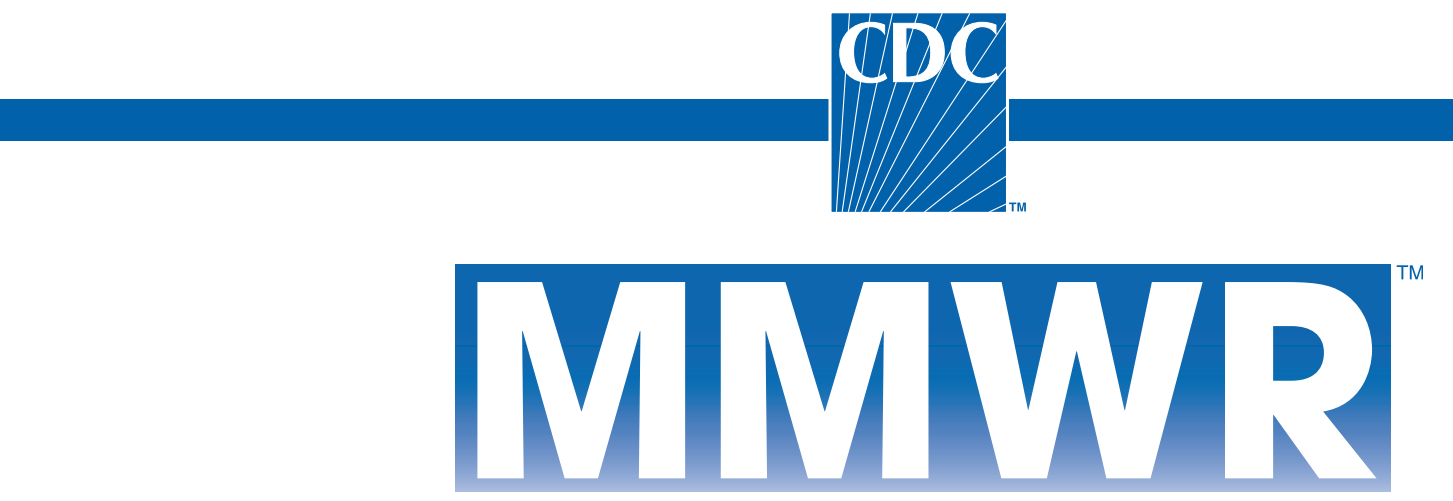

\title{
Morbidity and Mortality Weekly Report
} www.cdc.gov/mmwr

\section{Surveillance for Human West Nile Virus Disease - United States, 1999-2008}


The $M M W R$ series of publications is published by the Office of Surveillance, Epidemiology, and Laboratory Services, Centers for Disease Control and Prevention (CDC), U.S. Department of Health and Human Services, Atlanta, GA 30333.

Suggested Citation: Centers for Disease Control and Prevention. [Title]. Surveillance Summaries, [Date]. MMWR 2010;59(No. SS-\#).

\section{Centers for Disease Control and Prevention}

Thomas R. Frieden, MD, MPH

$$
\text { Director }
$$

Peter A. Briss, MD, MPH

Acting Associate Director for Science

James W. Stephens, PhD

Office of the Associate Director for Science

Stephen B. Thacker, MD, MSc

$$
\text { Deputy Director for }
$$

Surveillance, Epidemiology, and Laboratory Services

\section{Editorial and Production Staff}

Frederic E. Shaw, MD, JD

Editor, MMWR Series

Christine G. Casey, MD

Deputy Editor, MMWR Series

Teresa F. Rutledge

Managing Editor, MMWR Series

David C. Johnson

Lead Technical Writer-Editor

Catherine B. Lansdowne, MS Project Editor

Martha F. Boyd

Lead Visual Information Specialist

Malbea A. LaPete

Stephen R. Spriggs

Terraye M. Starr

Visual Information Specialists

Kim L. Bright

Quang M. Doan, MBA

Phyllis H. King

Information Technology Specialists

\section{Editorial Board}

William L. Roper, MD, MPH, Chapel Hill, NC, Chairman Virginia A. Caine, MD, Indianapolis, IN

Jonathan E. Fielding, MD, MPH, MBA, Los Angeles, CA

David W. Fleming, MD, Seattle, WA

William E. Halperin, MD, DrPH, MPH, Newark, NJ

King K. Holmes, MD, PhD, Seattle, WA

Deborah Holtzman, PhD, Atlanta, GA John K. Iglehart, Bethesda, MD

Dennis G. Maki, MD, Madison, WI

Sue Mallonee, MPH, Oklahoma City, OK

Patricia Quinlisk, MD, MPH, Des Moines, IA

Patrick L. Remington, MD, MPH, Madison, WI

Barbara K. Rimer, DrPH, Chapel Hill, NC

John V. Rullan, MD, MPH, San Juan, PR

William Schaffner, MD, Nashville, TN Anne Schuchat, MD, Atlanta, GA

Dixie E. Snider, MD, MPH, Atlanta, GA John W. Ward, MD, Atlanta, GA

\section{CONTENTS}

Introduction

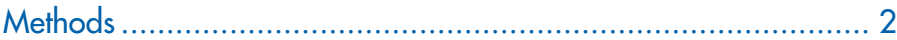

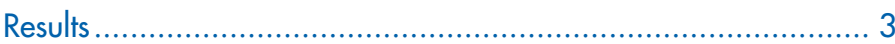

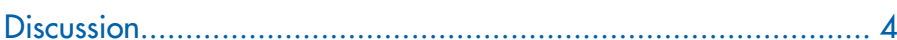

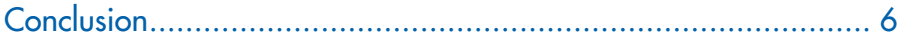

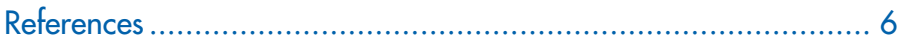 6}




\title{
Surveillance for Human West Nile Virus Disease - United States, 1999-2008
}

\author{
Nicole P. Lindsey, MS, J. Erin Staples, MD, PhD, Jennifer A. Lehman, Marc Fischer, MD \\ Division of Vector-Borne Infectious Diseases, National Center for Emerging and Zoonotic Infectious Diseases
}

\begin{abstract}
Problem/Condition: West Nile virus (WNV) is an arthropod-borne virus (arbovirus) in the family Flaviviridae and is the leading cause of arboviral disease in the United States. An estimated $80 \%$ of WNV infections are asymptomatic. Most symptomatic persons develop an acute systemic febrile illness that often includes headache, myalgia, arthralgia, rash, or gastrointestinal symptoms. Less than $1 \%$ of infected persons develop neuroinvasive disease, which typically presents as encephalitis, meningitis, or acute flaccid paralysis.
\end{abstract}

Reporting Period: 1999-2008.

Description of System: WNV disease is a nationally notifiable disease with standardized case definitions. State and metropolitan heath departments report cases to CDC through ArboNET, an electronic passive surveillance system. Variables collected include patient age, sex, race, county and state of residence, date of illness onset, clinical syndrome, and outcome of illness.

Results: During 1999-2008, a total of 28,961 confirmed and probable cases of WNV disease, including 11,822 (41\%) WNV neuroinvasive disease cases, were reported to CDC from 47 states and the District of Columbia. No cases were reported from Alaska, Hawaii, Maine, or any U.S. territories. A total of $93 \%$ of all WNV patients had illness onset during July-September. The national incidence of WNV neuroinvasive disease peaked in 2002 (1.02 cases per 100,000 population) and was stable during 2004-2007 (mean annual incidence: 0.44 ; range: 0.39-0.50). In 2008, the incidence was 0.23 per 100,000 population, compared with 0.41 in 2007 and 0.50 in 2006. During 1999-2008, the highest incidence of neuroinvasive disease occurred in West North Central and Mountain states. Neuroinvasive disease incidence increased with increasing age, with the highest incidence (1.35 cases per 100,000 population) occurring among persons aged $\geq 70$ years. The hospitalization rate and case-fatality ratio increased with increasing age among persons with neuroinvasive disease.

Interpretation: The stability in reported incidence of neuroinvasive disease during 2004-2007 might represent an endemic level of WNV transmission. Whether the incidence reported in 2008 represents a decrease that will continue is unknown; variations in vectors, avian amplifying hosts, human activity, and environmental factors make predicting future WNV transmission levels difficult.

Public Health Action: Surveillance of WNV disease is important for detecting and monitoring seasonal epidemics and targeting prevention and control activities. Public health education programs should focus on older persons, who are at increased risk for neurologic disease and poor clinical outcomes. In the absence of an effective human vaccine, WNV disease prevention depends on community-level mosquito control and household and personal protection measures.

\section{Introduction}

West Nile virus (WNV), an arthropod-borne virus (i.e., arbovirus) in the family Flaviviridae, was first detected in the United States in 1999 (1). WNV is maintained in nature in a mosquito-bird-mosquito transmission cycle primarily involving Culex species mosquitoes, particularly $C x$. pipiens,

Corresponding author: Nicole Lindsey, MS, Division of VectorBorne Infectious Diseases, CDC, 3150 Rampart Road, Fort Collins, CO 80521. Telephone: 970-266-3595; Fax: 970-266-3568; E-mail: nplindsey@cdc.gov.
$C x$. tarsalis, and $C x$. quinquefasciatus $(2,3)$. Birds are the natural reservoir hosts for WNV. When infected with WNV, many avian species develop transient viremia levels that are high enough to infect feeding mosquitoes (4). Birds commonly survive their infections and develop permanent immunity, although certain species become ill and die (5). Humans are considered dead-end hosts; they do not develop viremia levels of a sufficient titer to allow virus transmission to feeding mosquitoes (G).

Since WNV was first detected in 1999, the virus has become the leading cause of arboviral encephalitis in the United States. Approximately $80 \%$ of WNV infections are asymptomatic (7). 
Most symptomatic persons experience an acute systemic febrile illness that often includes headache, myalgia, or arthralgia; gastrointestinal symptoms and a transient maculopapular rash also are commonly reported $(2,8-11)$. Less than $1 \%$ of infected persons develop neuroinvasive disease, which typically manifests as encephalitis, meningoencephalitis, meningitis, or poliomyelitis-like acute flaccid paralysis (AFP) $(6-8,10)$. Risk factors for developing neuroinvasive disease after WNV infection include older age and a history of solid organ transplantation (because of related immune suppression) and might also include other immunocompromising conditions, diabetes, and hypertension $(1,6,12-18)$.

The case definition for neuroinvasive arboviral disease was first developed in 1990 and subsequently was revised in 1996, 2001, and 2004 (19-22). The first human cases of WNV disease acquired in the United States were identified in New York City, New York, in 1999 (1). In 2000, CDC collaborated with state and local health departments to establish ArboNET, an electronic passive surveillance system, to monitor WNV infections in humans, mosquitoes, birds, and other animals. Initially, human surveillance focused on cases of neuroinvasive disease using a standard case definition (23). Neuroinvasive disease caused by WNV became a nationally notifiable disease in 2001 (21). Nonneuroinvasive arboviral disease did not become a nationally notifiable disease until 2004 (22).

The goals of national surveillance for WNV disease are to 1) assess the public health impact of the disease, 2) determine the need for public health intervention programs, 3) identify risk factors for infection, 4) determine which populations are at high risk for infection, and 5) identify geographic areas that would benefit from targeted interventions (24). This report summarizes the national WNV disease surveillance data for 1999-2008, including demographic characteristics, seasonal patterns, and geographic distribution of reported WNV disease cases.

\section{Methods}

\section{Surveillance Case Definitions for Neuroinvasive and Nonneuroinvasive Domestic Arboviral Diseases}

The probable and confirmed case definitions for neuroinvasive and nonneuroinvasive domestic arboviral diseases were approved by the Council of State and Territorial Epidemiologists (CSTE) in 2004 (22). A case must meet at least one of the clinical criteria and at least one of the laboratory criteria described in the following sections.

\section{Clinical Criteria for Diagnosis}

Neuroinvasive disease requires the presence of fever and at least one of the following, as documented by a physician and in the absence of a more likely clinical explanation: 1) acutely altered mental status (e.g., disorientation, obtundation, stupor, or coma), 2) other acute signs of central or peripheral neurologic dysfunction (e.g., paresis or paralysis, nerve palsies, sensory deficits, abnormal reflexes, generalized convulsions, or abnormal movements), or 3) pleocytosis (increased white blood cell concentration in cerebrospinal fluid) associated with illness clinically compatible with meningitis (e.g., headache or stiff neck).

Nonneuroinvasive disease requires, at a minimum, the presence of fever, as measured by the patient or clinician, the absence of neuroinvasive disease, and the absence of a more likely clinical explanation for the illness. Involvement of nonneurologic organs (e.g., heart, pancreas, or liver) should be documented using standard clinical and laboratory criteria.

\section{Laboratory Criteria for Diagnosis}

For a case to be considered laboratory confirmed, at least one of the following criteria should be met: 1) a fourfold or greater change in virus-specific serum antibody titer; or 2) isolation of virus from or detection of specific viral antigen or genomic sequences in tissue, blood, cerebrospinal fluid, or other body fluid; or 3) virus-specific immunoglobulin M (IgM) antibodies demonstrated in cerebrospinal fluid by antibodycapture enzyme immunoassay (EIA); or 4) virus-specific IgM antibodies demonstrated in serum by antibody-capture EIA and confirmed by demonstration of virus-specific serum immunoglobulin $\mathrm{G}(\mathrm{IgG})$ antibodies in the same specimen or a later specimen by another serologic assay (e.g., neutralization or hemagglutination inhibition). Probable cases have 1) a stable (twofold or smaller change) but elevated titer of virus-specific serum antibodies or 2) virus-specific serum IgM antibodies detected by antibody-capture EIA but with no available results of a confirmatory test for virus-specific serum IgG antibodies in the same or a later specimen.

\section{Data Source}

Data for WNV disease cases that occurred in 1999 were obtained from a database managed collaboratively by the New York City Department of Health and Mental Hygiene, the New York State Department of Health, and CDC. Since 2000, state and metropolitan health departments have reported cases of WNV disease, a nationally notifiable disease, to CDC through ArboNET. State and local health departments are responsible for ensuring that reported cases meet the national case definition. Various methods have been used by health departments 
to identify cases, including passive surveillance, enhanced or active surveillance, and laboratory-based surveillance. Variables collected by ArboNET include patient age, sex, race, and county and state of residence; date of illness onset; case status (i.e., confirmed, probable, suspected, or not a case); clinical syndrome (e.g., encephalitis, meningitis, or uncomplicated fever); whether illness resulted in hospitalization; and whether the illness was fatal. Cases reported as encephalitis (including meningoencephalitis), meningitis, or acute flaccid paralysis (AFP) are collectively referred to as neuroinvasive disease; others are considered nonneuroinvasive disease. AFP can occur with or without encephalitis or meningitis. In this analysis, any case reported as AFP (with or without another clinical syndrome) was classified as AFP only and not included in the other categories. Asymptomatic human infections, which are typically identified by blood donor screening, also are reported. In 2004, the ArboNET system began collecting information regarding hospitalization and occurrence of AFP.

\section{Analysis}

The analysis of cases in this report is limited to those that meet the CSTE case definition for WNV disease (i.e., confirmed and probable cases) and that were reported to CDC during 1999-2008. Because of variability in completeness of reporting of nonneuroinvasive disease cases (25), descriptions of age-specific outcomes, geographic distribution, and age- and sex-specific incidences are only included for neuroinvasive disease cases. Annual U.S. incidence rates per 100,000 population and rates by state, county, age group, and sex were calculated using U.S. Census Bureau population estimates for July 1 of each year of the reporting period (1999-2008). Average annual incidence rates were calculated using July 1, 2004, population estimates.

\section{Results}

During 1999-2008, 28,961 cases of WNV disease were reported from 1,869 counties in 47 states and the District of Columbia (DC). No cases were reported from Alaska, Hawaii, Maine, or any U.S. territories. Of all cases reported, 11,822 (41\%) were classified as neuroinvasive disease and 17,139 (59\%) as nonneuroinvasive disease (Table 1 ). The majority of neuroinvasive disease cases (61\%) were classified as confirmed, whereas the majority of nonneuroinvasive disease cases $(71 \%)$ were classified as probable (Table 2 ). The proportion of reported cases classified as confirmed fluctuated during the reporting period (median 69\%; range: 46\%-100\%) and also varied by state (median 68\%; range: 9\%-100\%). Despite these variations, demographic characteristics and outcomes did not vary by case status. Because confirmed and probable cases meet the national case definitions and have laboratory evidence of WNV infection, confirmed and probable cases are combined for the remainder of this analysis.

Despite substantial geographic spread of the virus during 2000-2001, reported numbers of cases remained low $(<100$ per year) until 2002-2003, when human cases were first detected in the Midwest and Great Plains (Figure 1). By 2006, cases had been reported from all contiguous states except Maine. Although patients with WNV disease reported onset of illness dates in all weeks of the year, $93 \%$ of patients had onset of illness during July-September (Figure 2). The annual epidemic peak in the United States consistently occurs in August.

\section{Nonneuroinvasive Disease}

During 1999-2008, a total of 17,139 nonneuroinvasive WNV disease cases were reported. Males accounted for 52\% of cases (Table 3). Among the 16,956 patients for whom age was known, the median age was 47 years (range: 1 month-97 years). Approximately half ( $45 \%)$ of all cases occurred in persons aged 40-59 years. Among 11,288 patients for whom race data were available, 95\% were white. Among 9,501 patients for whom ethnicity data were available, $90 \%$ were non-Hispanic. Ninety-four percent of patients had illness onset during July-September (Figure 2). Among the 8,925 cases reported during 2004-2008, 1,843 (21\%) resulted in hospitalization. Eighty-six $(0.5 \%)$ of reported nonneuroinvasive disease cases were fatal. Among the 85 patients who died and for whom age was known, $70(82 \%)$ were aged $\geq 70$ years.

\section{Neuroinvasive Disease}

\section{Selected Demographic Characteristics and Clinical Outcomes}

During 1999-2008, 11,822 neuroinvasive disease cases were reported. Males accounted for $58 \%$ of cases (Table 3). Among the 11,769 cases with known age, the median age was 57 years (range: 1 month-99 years). Almost half (46\%) of all cases occurred in persons aged $\geq 60$ years. Among 6,690 patients for whom race data were available, $88 \%$ were white. Among 5,577 patients for whom ethnicity data were available, $82 \%$ were non-Hispanic. Ninety-one percent of patients had onset of illness during July-September. Among the 5,868 cases reported during 2004-2008, 86\% were hospitalized. Hospitalization rates were $>80 \%$ in all age groups but were higher among patients aged $\geq 50$ years $(92 \%)$ than among those aged $<50$ years (85\%). Overall, 1,045 (9\%) of neuroinvasive disease cases were fatal. The case-fatality ratio increased considerably with increasing age; $0.8 \%$ of cases among patients aged $<40$ 
years were fatal, compared with 3\% of cases among those aged 40-49 and 50-59 years (combined) and 17\% of those aged 60-69 and $\geq 70$ years (combined) (Figure 3).

\section{Selected Demographic Characteristics and Clinical Outcomes by Neuroinvasive Disease Syndrome}

Among neuroinvasive disease cases, 7,502 (63\%) were reported as encephalitis, 3,930 (33\%) as meningitis, and 311 $(3 \%)$ as AFP; in $79(<1 \%)$ cases, the type of neuroinvasive disease syndrome was unspecified (Table 4). Among all neuroinvasive disease syndromes, males accounted for the majority of cases. The median age of encephalitis patients (60 years) was higher than that of meningitis patients ( 46 years) or AFP patients ( 55 years). Among all syndromes, most patients with reported race were reported as white. Among all syndromes, approximately $90 \%$ of patients had onset of illness during July-September (Figure 2). Hospitalization rates were similar among patients with illness classified encephalitis (86\%), meningitis $(81 \%)$, and AFP (82\%). However, $12 \%$ of cases classified as encephalitis and AFP were fatal, compared with $2 \%$ of those classified as meningitis. Like all neuroinvasive disease cases combined, hospitalization rates and case-fatality ratios increased with increasing age for each syndrome.

\section{Incidence by State and County}

The national average annual incidence of neuroinvasive disease during $1999-2008$ was 0.40 per 100,000 population (range: 0.01-1.02) (Figure 4). Despite substantial geographic spread of the virus during 1999-2001, neuroinvasive disease incidence remained low until 2002 (1.02) and 2003 (0.99), when outbreaks centered in the Midwest and Great Plains occurred. The national incidence of neuroinvasive disease was stable during 2004-2007 (mean: 0.44; range: 0.39-0.50). In 2008 , the incidence was 0.23 per 100,000 population, compared with 0.41 in 2007 and 0.50 in 2006. Similar trends over time were observed for each clinical syndrome (encephalitis, meningitis, and AFP).

Neuroinvasive disease cases were reported from 46 states and DC; $63 \%$ of all cases were reported from 10 states: Arizona, California, Colorado, Illinois, Louisiana, Michigan, Mississippi, Nebraska, South Dakota, and Texas. No neuroinvasive disease cases were reported from Alaska, Hawaii, Maine, or Vermont. The average annual incidence for all states ranged from $<0.1$ per 100,000 population (New Hampshire, North Carolina, South Carolina, Washington, and West Virginia) to 4.0 per 100,000 (South Dakota) (Table 5). States with the highest average annual incidence were in the West North Central and Mountain states (Table 5, Figure 5). Colorado, Idaho, Louisiana, Mississippi, Montana, Nebraska, North
Dakota, South Dakota, and Wyoming had an average annual incidence of $\geq 1$ case per 100,000 population. Counties with the highest average annual incidences also were clustered in West North Central and Mountain states (Figure 6).

\section{Incidence by Age and Sex}

The average annual incidence of neuroinvasive disease increased steadily with increasing age, ranging from 0.05 per 100,000 among persons aged $<10$ years to 1.35 among those aged $\geq 70$ years (Figure 7 ). Similarly, the average annual incidence of encephalitis increased with increasing age, ranging from 0.02 per 100,000 among persons aged $<10$ years to 1.10 among those aged $\geq 70$ years (Figure 8 ). The average annual incidences of meningitis and AFP increased with increasing age among persons aged $<40$ years but did not change among persons aged $\geq 40$ years.

Neuroinvasive disease incidence was higher among males (0.48 per 100,000 population) than among females (0.33), especially among persons aged $\geq 60$ years, for whom the incidence in men was twice that in women (Figure 9). Similar differences by sex were observed among the various neuroinvasive disease syndromes (i.e., encephalitis, meningitis, and AFP).

\section{Alternate Routes of Transmission}

Since 2003, ArboNET has collected information on known or possible non-mosquito modes of WNV transmission. Of the 24,656 cases reported during 2003-2008, 11 (0.04\%) were reported as having been acquired in a laboratory setting. Although not confirmed as the source of infection in all cases, $36(0.1 \%)$ patients with WNV disease had received a blood transfusion or organ transplant within 30 days of illness onset. Of 11,026 females with WNV disease reported since 2003, 124 (1\%) had been pregnant at the time of illness onset. Two infant cases were reported as having been acquired in utero. Although nine cases were reported to have been in breastfed infants, the probable source of infection in most of these instances was considered to be mosquitoes, not breastfeeding.

\section{Discussion}

\section{Incidence Patterns and Transmission}

National surveillance for WNV provides data needed for monitoring potential changes in disease transmission patterns and developing prevention strategies. Since WNV was first detected in the United States in 1999, the annual incidence of neuroinvasive disease has fluctuated considerably. The stability in incidence during 2004-2007 might represent an endemic level of WNV transmission in the contiguous United States. However, whether the incidence reported in 2008 represents 
a decrease that will continue is unclear. The complex biology of vectors and avian amplifying hosts, as well as variations in human activity and environmental factors, make predicting future transmission difficult. Although WNV human disease cases have been detected in all geographic regions of the contiguous United States, the highest incidence of neuroinvasive disease consistently occurs in the West Central and Mountain regions. The higher incidence observed in these regions most likely results from the high efficiency of $C x$. tarsalis as both an epizootic and epidemic WNV vector $(3,25)$.

Neuroinvasive disease occurs in all age groups and both sexes but disproportionately affects older persons and males, particularly older men. The association between increasing age and increasing neuroinvasive disease incidence has been well described $(1,16,26,27)$. The reasons for the higher incidence of neuroinvasive disease among males are unknown, but this finding might be related to either reporting biases or the presence of underlying medical conditions $(1,6,12-18)$ that might be risk factors for the development of neuroinvasive disease after WNV infection. Although the development of neuroinvasive disease after WNV infection occurs more frequently among males, the risk for initial infection with WNV has not been found to be significantly higher among males, according to serosurveys and studies among blood donors $(26,28-30)$. Hospitalization rates for neuroinvasive disease case-patients are high (approximately $80 \%$ ) in all age groups, but case-fatality ratios increase with increasing age.

The proportion of total cases reported as neuroinvasive disease is likely higher than the actual proportion because more severe cases are more likely to be detected and reported than milder cases (i.e., nonneuroinvasive disease cases). The results of a 1999 serosurvey in New York estimate that approximately one case of neuroinvasive disease occurs per 140 infected persons and approximately $19 \%$ of infected persons develop nonneuroinvasive disease (7). Therefore, assuming that all neuroinvasive disease cases were reported $(\mathrm{N}=11,822)$, an estimated 1,655,080 WNV infections occurred during 1999-2008, resulting in approximately 314,465 (19\% of total infections) nonneuroinvasive WNV disease cases. However, only 17,139 nonneuroinvasive cases were reported to ArboNET, which is $5 \%$ of the number of nonneuroinvasive cases that are estimated to have occurred. Because of the high number of unreported nonneuroinvasive cases, the overall case-fatality ratio for all cases of WNV disease is likely lower than the percentage (4\%) calculated in this report and published elsewhere (23).

Non-mosquito WNV transmission through blood transfusions, transplanted organs, transplacentally from mother to fetus, and via exposure in a laboratory setting has been reported (31-37). As previously mentioned, transmission via breast milk has also been reported rarely; however, such reports have not been conclusively confirmed (38). Transfusion-associated WNV transmission was first detected in 2002, when 23 transfusion recipients were infected after receiving platelets, red blood cells, or fresh frozen plasma from 16 viremic blood donors (31). National blood donation screening began in 2003 but has not eliminated WNV transfusion transmission. Through 2008, 10 breakthrough WNV transmissions occurred from blood donations that had virus levels below the limit of detection (32-34). Transmission via donated organs also was first documented in 2002, when WNV infection developed in four recipients of organs from a common donor (35). WNV transmission via organ transplant was documented again in 2005 when WNV infection developed in three of four organ recipients (36). Intrauterine transmission of WNV was first documented in 2002 (37). A follow-up study of 77 women infected with WNV during pregnancy found that 71 women gave birth to 72 live infants, and most were born healthy (39). Congenital WNV infection, rather than infection after birth, could not be proven in any of the infants; however, three infants had laboratory evidence of WNV infection that might have been congenitally acquired. A study of 549 infants born to 547 mothers who were pregnant during a 2003 WNV outbreak in Colorado found evidence of WNV infection in 4\% of the mothers and none of the infants $(40)$. Birth outcomes were similar among infants born to mothers with and without evidence of WNV infection during pregnancy.

\section{Limitations}

The findings in this report are subject to at least four limitations. First, ArboNET is a passive surveillance system that is dependent on clinicians considering the diagnosis of an arboviral disease, obtaining the appropriate diagnostic test, and reporting positive results to public health authorities. Therefore, diagnosis and reporting are likely incomplete, and the incidence of arboviral diseases is likely underestimated, particularly for cases of nonneuroinvasive disease.

Second, missing race and ethnicity data were not imputed for WNV case reports because of uncertainty about whether imputed data would increase the validity and precision of the reported estimates; therefore, these results should be interpreted with caution.

Third, because ArboNET does not collect information regarding clinical signs and symptoms or laboratory findings (e.g., cerebrospinal fluid findings), misclassification of the various neurologic syndromes caused by WNV (i.e., encephalitis, meningitis, and AFP) cannot be detected. Although each WNV illness is discussed as a unique condition in this report, the clinical characteristics of WNV disease cases are not always clear, and illnesses can overlap. In addition, ArboNET does not 
collect information regarding the specific laboratory methods used to confirm each case. The most common laboratory tests used to diagnose arboviral disease are IgM EIAs. Although these assays are relatively specific, false-positive results and cross-reactions occur between WNV and other flaviviruses (e.g., St. Louis encephalitis). Positive IgM results should be confirmed by additional tests, especially plaque-reduction neutralization. However, such confirmatory testing often is not performed.

Finally, ArboNET data may not be representative of differences in disease incidence over time or by jurisdiction because arboviral disease awareness, laboratory testing capacity, and case reporting might vary annually and by county, state, or region. Reported cases of neuroinvasive disease are considered the most accurate indicator of arboviral activity in humans because of the substantial associated morbidity. The severity of neuroinvasive disease increases the likelihood that a patient will seek medical care, have appropriate diagnostic testing performed, and have the illness reported to public health authorities. In contrast, reported cases of nonneuroinvasive arboviral disease are more likely to be affected by disease awareness and health-care-seeking behavior in different communities and by the availability and specificity of laboratory tests performed. Surveillance data for nonneuroinvasive disease should be interpreted with caution and generally should not be used to make comparisons between geographic areas or over time.

\section{Conclusion}

WNV has become endemic in the United States, with ongoing potential for seasonal epidemic transmission at the local, regional, or national level. Although annual WNV disease incidence varies substantially, the annual recurrence of WNV activity suggests that transmission will continue. Public health education programs should focus on older adults because they are at increased risk for neuroinvasive disease and death. In addition, more complete reporting of race and ethnicity data might reveal differences that also could be addressed by targeted public health education programs. In the absence of an effective human vaccine, the cornerstones of WNV disease prevention will continue to be 1) community-level mosquito control (larviciding, adulticiding, and breeding-site reduction), 2) peridomestic measures (repairing and installing door and window screens, using air conditioning, and reducing breeding sites), and 3) personal protection measures (use of repellents, use of protective clothing, and avoidance of outdoor exposure when mosquitoes are most active). WNV surveillance continues to be important for monitoring seasonal WNV activity and targeting prevention and control activities.

\section{Acknowledgments}

This report is based, in part, on contributions by state, District of Columbia, and New York City surveillance coordinators; Edward B. Hayes, MD; Grant L. Campbell, MD; Sonja J. Olsen, PhD; and Ian T. Williams, PhD.

\section{References}

1. Nash D, Mostashari F, Fine A, et al. The outbreak of West Nile virus infection in the New York City area in 1999. N Engl J Med 2001;344:1807-14.

2. Hayes CG. West Nile fever. In: Monath TP, ed. The arboviruses: epidemiology and ecology, vol V. Boca Raton, FL: CRC Press, 1989;59-88.

3. Turell MJ, Dohm DJ, Sardelis MR, Oguinn ML, Andreadis TG, Blow JA. An update on the potential of North American mosquitoes (Diptera: Culicidae) to transmit West Nile virus. J Med Entomol 2005;42:57-62.

4. Work TH, Hurlbut HS, Taylor RM. Indigenous wild birds of the Nile delta as potential West Nile virus circulating reservoirs. Am J Trop Med Hyg 1955;4:872-88.

5. Komar N, Panella NA, Burns JE, Dusza SW, Mascarenhas TM, Talbot TO. Serologic evidence for West Nile virus infection in birds in the New York City vicinity during an outbreak in 1999. Emerg Infect Dis 2001;7:621-25.

6. Hayes EB, Komar N, Nasci RS, Montgomery SP, O’Leary DR, Campbell GL. Epidemiology and transmission dynamics of West Nile virus disease. Emerg Infect Dis 2005;11:1167-73.

7. Mostashari F, Bunning ML, Kitsutani PT, et al. Epidemic West Nile encephalitis, New York, 1999: results of a household-based seroepidemiological survey. Lancet 2001;358:261-4.

8. Campbell GL, Marfin AA, Lanciotti RS, Gubler DJ. West Nile virus. Lancet Infect Dis 2002;2:519-29.

9. Watson JT, Pertel PE, Jones RC, et al. Clinical characteristics and functional outcomes of West Nile Fever. Ann Intern Med 2004;141:360-5.

10. Sejvar JJ, Marfin AA. Manifestations of West Nile neuroinvasive disease. Rev Med Virol 2006;16:209-24.

11. Hayes EB, Sejvar JJ, Zaki SR, Lanciotti RS, Bode AV, Campbell GL. Virology, pathology, and clinical manifestations of West Nile virus disease. Emerg Infect Dis 2005;11:1174-9.

12. Kumar D, Prasad GV, Zaltzman J, Levy GA, Humar A. Communityacquired West Nile virus infection in solid-organ transplant recipients. Transplantation 2004;77:399-402.

13. Han LL, Popovici F, Alexander JP Jr, et al. Risk factors for West Nile virus infection and meningoencephalitis, Romania, 1996. J Infect Dis 1999;179:230-3.

14. Jean CM, Honarmand S, Louie JK, Glaser CA. Risk factors for West Nile virus neuroinvasive disease, California, 2005. Emerg Infect Dis 2007;13:1918-20.

15. Murray K, Baraniuk S, Resnick M, et al. Risk factors for encephalitis and death from West Nile virus infection. Epidemiol Infect 2006;134:1325-32.

16. O'Leary DR, Marfin AA, Montgomery SP, et al. The epidemic of West Nile virus in the United States, 2002. Vector Borne Zoonotic Dis 2004; 4:61-70.

17. Patnaik JL, Harmon H, Vogt RL. Follow-up of 2003 human West Nile virus infections, Denver, Colorado. Emerg Infect Dis 2006;12:1129-31.

18. Bode AV, Sejvar JJ, Pape WJ, Campbell GL, Marfin AA. West Nile virus disease: a descriptive study of 228 patients hospitalized in a 4-county region of Colorado in 2003. Clin Infect Dis 2006;42:1234-40.

19. CDC. Case definitions for public health surveillance. MMWR 1990;39(No. RR-13).

20. CDC. Case definitions for infectious conditions under public health surveillance. MMWR 1997;46(No. RR-10). 
21. CDC. Case definitions for infectious conditions under public health surveillance: encephalitis or meningitis, arboviral. Atlanta, GA: CDC; 2001. Available at http://www.cdc.gov/ncphi/disss/nndss/casedef/ encephalitiscurrent.htm. Accessed January 6, 2010.

22. CDC. Case definitions for infectious conditions under public health surveillance: neuroinvasive and non-neuroinvasive domestic arboviral diseases. Atlanta, GA: CDC; 2004. Available at http://www.cdc.gov/ epo/dphsi/casedef/arboviral_current.htm. Accessed January 6, 2010.

23. CDC. Epidemic/epizootic West Nile virus in the United States: guidelines for surveillance, prevention, and control. CDC; 1999. Available at http://www.cdc.gov/ncidod/dvbid/westnile/resources/wnvguidelines 1999.pdf. Accessed January 6, 2010.

24. CDC. Epidemic/epizootic West Nile virus in the United States: revised guidelines for surveillance, prevention, and control. Atlanta, GA: CDC; 2003. Available at http://www.cdc.gov/ncidod/dvbid/westnile/resources/ wnvguidelines2003.pdf. Accessed January 6, 2010.

25. Lindsey NP, Kuhn S, Campbell GL, Hayes EB. West Nile virus neuroinvasive disease incidence in the United States, 2002-2006. Vector Borne Zoonotic Dis 2008;8:35-9.

26. Tsai TF, Popovici F, Cernescu C, Campbell GL, Nedelcu NI. West Nile encephalitis epidemic in southeastern Romania. Lancet 1998;352:767-71.

27. Platonov AE, Shipulin GA, Shipulina OY, et al. Outbreak of West Nile virus infection, Volgograd Region, Russia, 1999. Emerg Infect Dis 2001;7:128-32.

28. Brown JA, Factor DL, Tkachenko N, et al. West Nile viremic blood donors and risk factors for subsequent West Nile fever. Vector Borne Zoonotic Dis 2007;7:479-88.

29. Murphy TD, Grandpre J, Novick SL, Seys SA, Harris RW, Musgrave K. West Nile virus infection among health-fair participants, Wyoming 2003: assessment of symptoms and risk factors. Vector Borne Zoonotic Dis 2005;5:246-51.
30. CDC. Serosurveys for West Nile virus infection-New York and Connecticut counties, 2000. MMWR 2001;50;37-9.

31. Pealer LN, Marfin AA, Petersen LR, et al. Transmission of West Nile virus through blood transfusion in the United States in 2002. N Engl J Med 2003;349:1236-45.

32. CDC. West Nile virus transmission through blood transfusion-South Dakota, 2006. MMWR 2007;56:76-9.

33. Petersen LR, Epstein JS. Problem solved? West Nile virus and transfusion safety. N Engl J Med 2005;353:516-7.

34. CDC. West Nile virus transmission via organ transplantation and blood transfusion-Louisiana, 2008. MMWR 2009; 58:1263-7.

35. Iwamoto M, Jernigan DB, Guasch A, et al. Transmission of West Nile virus from an organ donor to four transplant recipients. N Engl J Med 2003;348:2196-203.

36. CDC. West Nile virus infections in organ transplant recipientsNew York and Pennsylvania, August-September, 2005. MMWR 2005;54:1021-3.

37. Alpert SG, Fergerson J, Noel LP. Intrauterine West Nile virus: ocular and systemic findings. Am J Ophthalmol 2003;136:733-5.

38. Hinckley AF, O'Leary DR, Hayes EB. Transmission of West Nile virus through human breast milk seems to be rare. Pediatrics 2007;119:e666-71.

39. O'Leary DR, Kuhn S, Kniss KL, et al. Birth outcomes following West Nile Virus infection of pregnant women in the United States: 2003-2004. Pediatrics 2006;117:e537-45.

40. Paisley JE, Hinckley AF, O'Leary DR, et al. West Nile virus infection among pregnant women in a northern Colorado community, 2003 to 2004. Pediatrics 2006;117:814-20. 
FIGURE 1. Year of first reported human West Nile virus disease case, by state — United States, ${ }^{*}$ 1999-2008

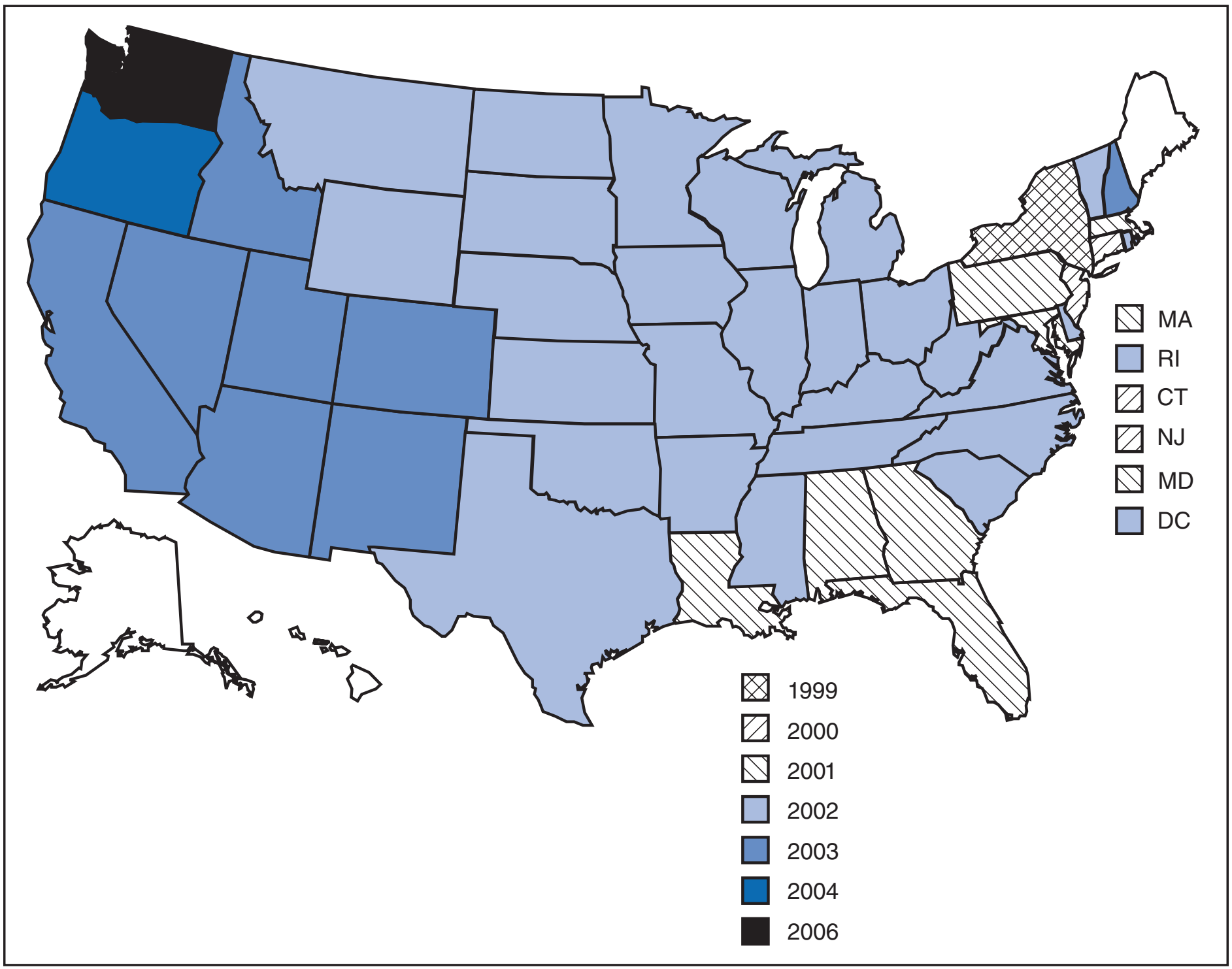

* No cases were reported from Alaska, Hawaii, Maine, or any U.S. territories. 
FIGURE 2. West Nile virus disease cases $(\mathrm{N}=\mathbf{2 8 , 9 6 1 )}$, by week of illness onset — United States, 1999-2008

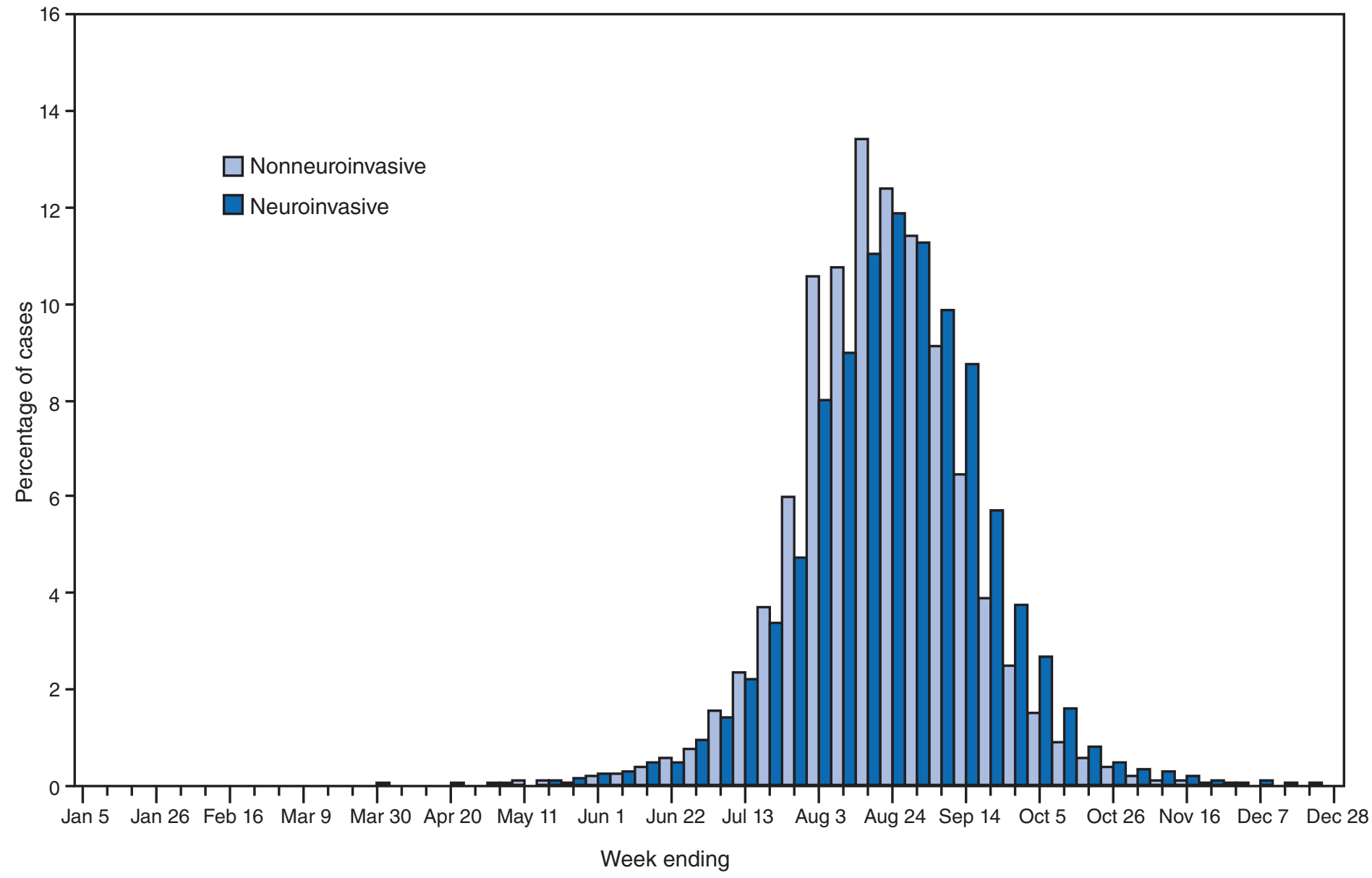


FIGURE 3. West Nile virus neuroinvasive disease case-fatality ratios, by age group - United States, 1999-2008

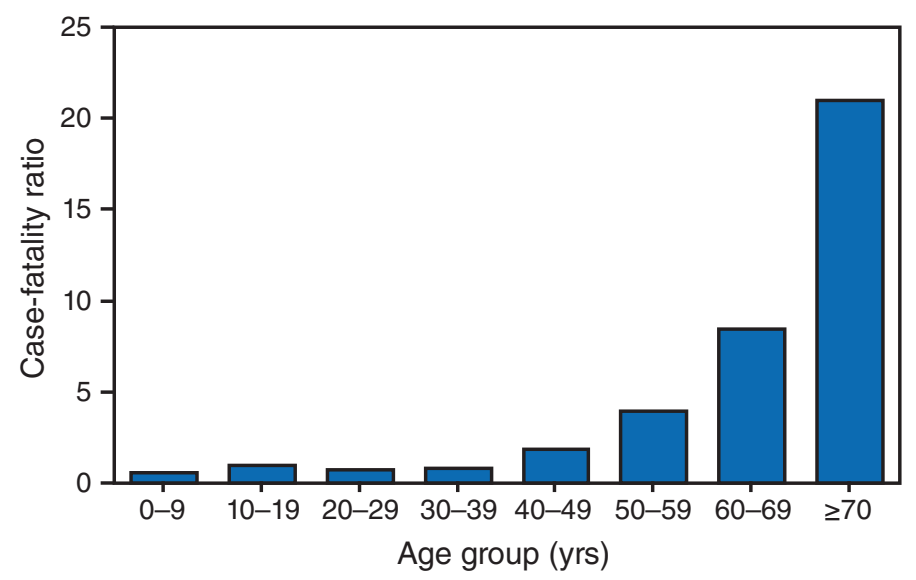

FIGURE 4. Annual incidence* of West Nile virus neuroinvasive disease $(n=11,822)$, by year - United States, 1999-2008

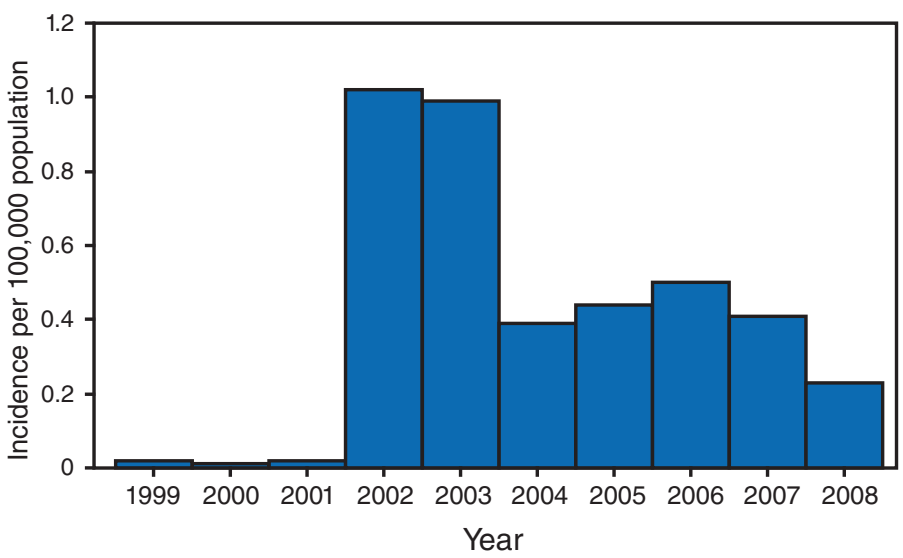

* Calculated using U.S. Census Bureau population estimates for July 1 of each year of the reporting period. 
FIGURE 5. Average annual incidence ${ }^{\star}$ per 100,000 population of West Nile virus neuroinvasive disease $(n=11,822)$, by state of residence - United States, 1999-2008

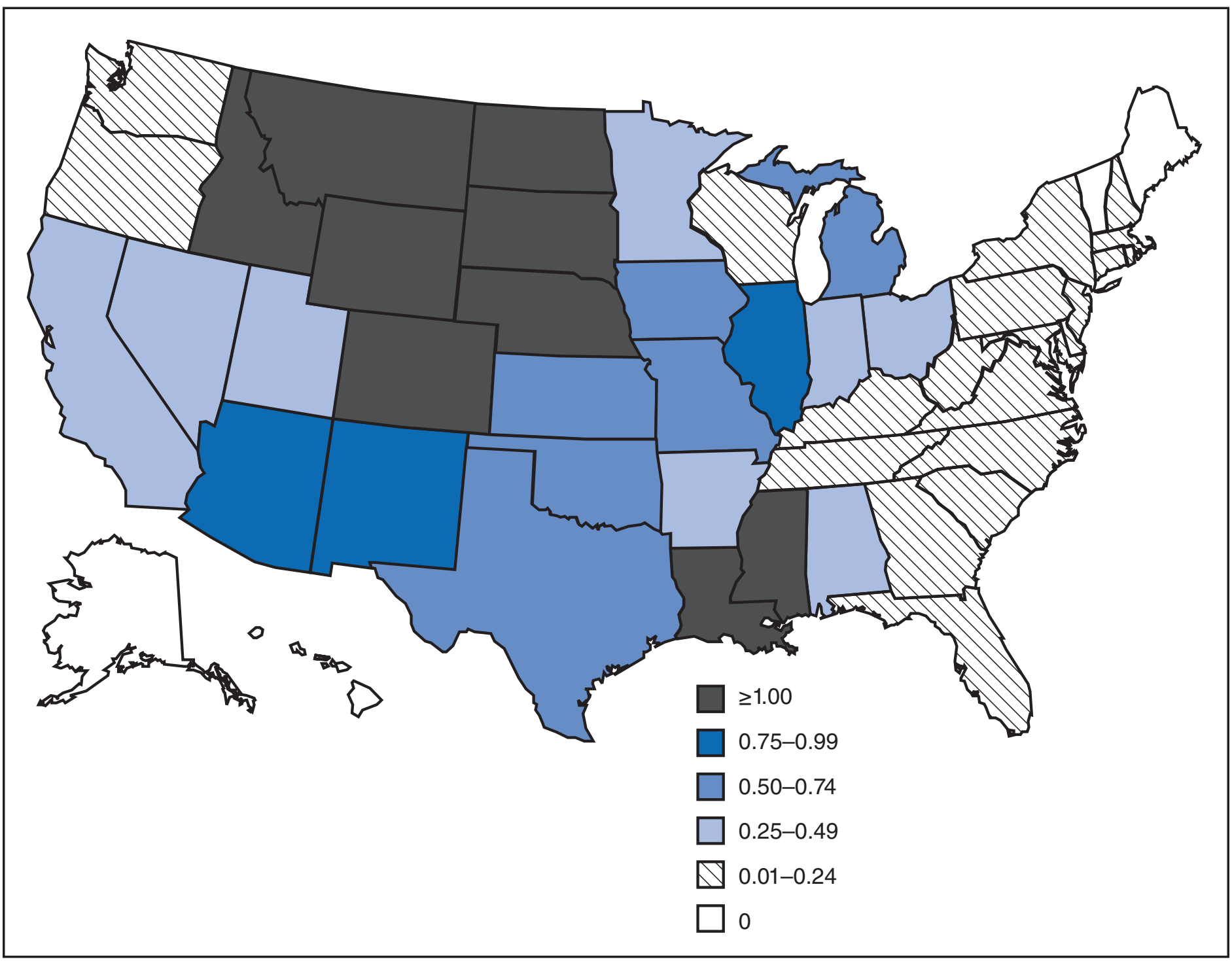

*Calculated using U.S. Census Bureau population estimates for July 1, 2004. 
FIGURE 6. Average annual incidence* per 100,000 population of West Nile virus neuroinvasive disease $(n=11,822)$, by county of residence - United States, 1999-2008

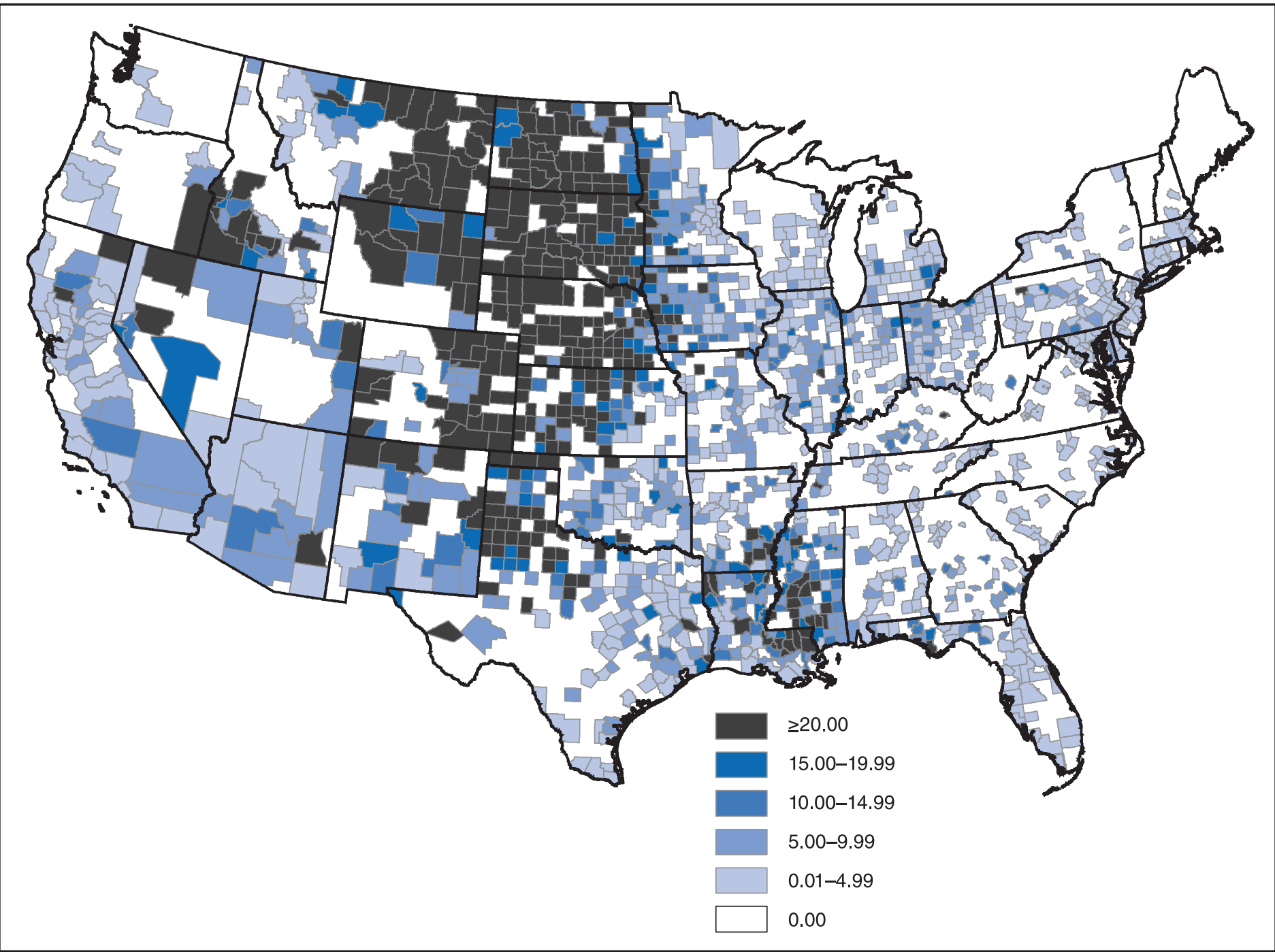

* Calculated using U.S. Census Bureau population estimates for July 1, 2004. 
FIGURE 7. Average annual incidence* of West Nile virus neuroinvasive disease $(n=11,822)$, by age group — United States, 1999-2008

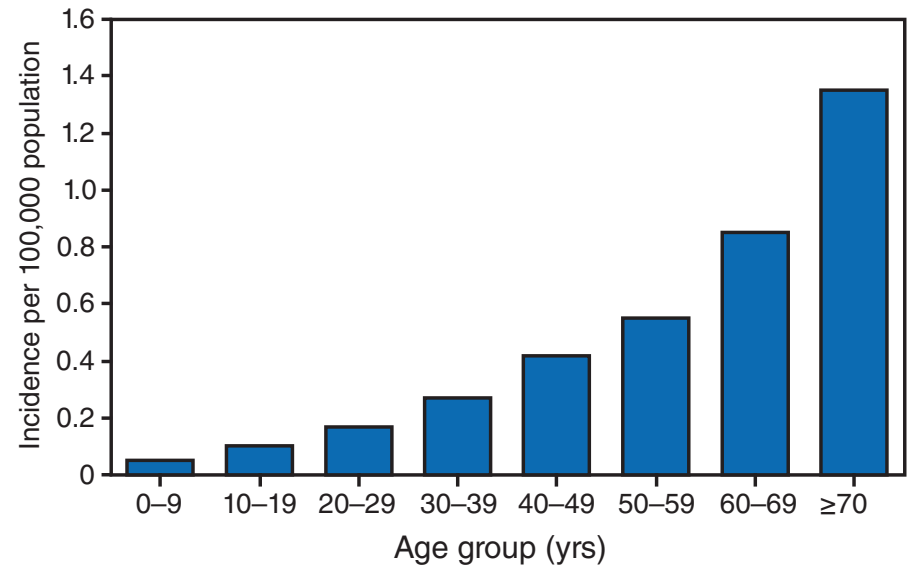

* Calculated using U.S. Census Bureau population estimates for July 1, 2004.

FIGURE 8. Average annual incidence* of West Nile virus neuroinvasive disease $(n=11,822)$, by age group and clinical syndrome - United States, 1999-2008

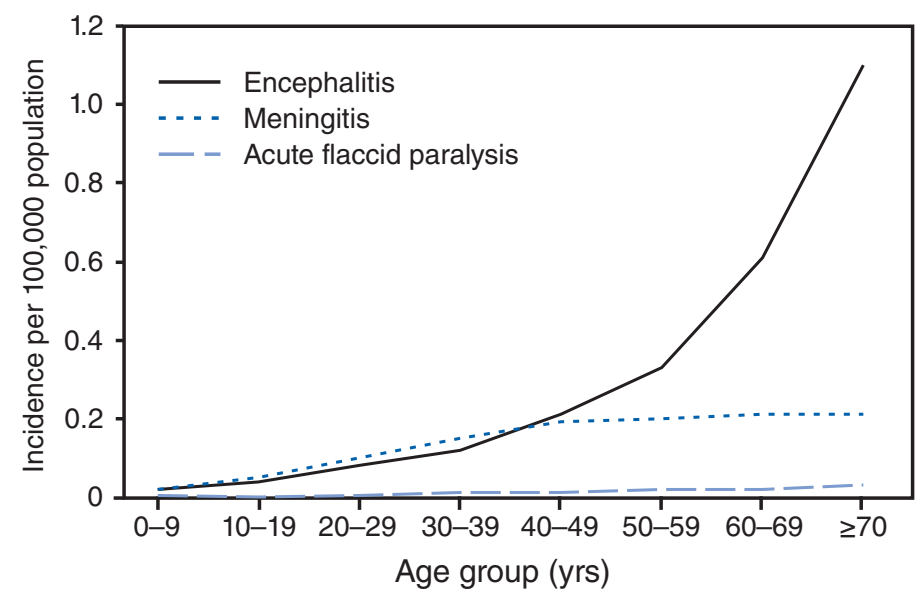

* Calculated using U.S. Census Bureau population estimates for July 1 , 2004.
FIGURE 9. Average annual incidence* of West Nile virus neuroinvasive disease $(n=11,822)$, by age group and sex - United States, 1999-2008

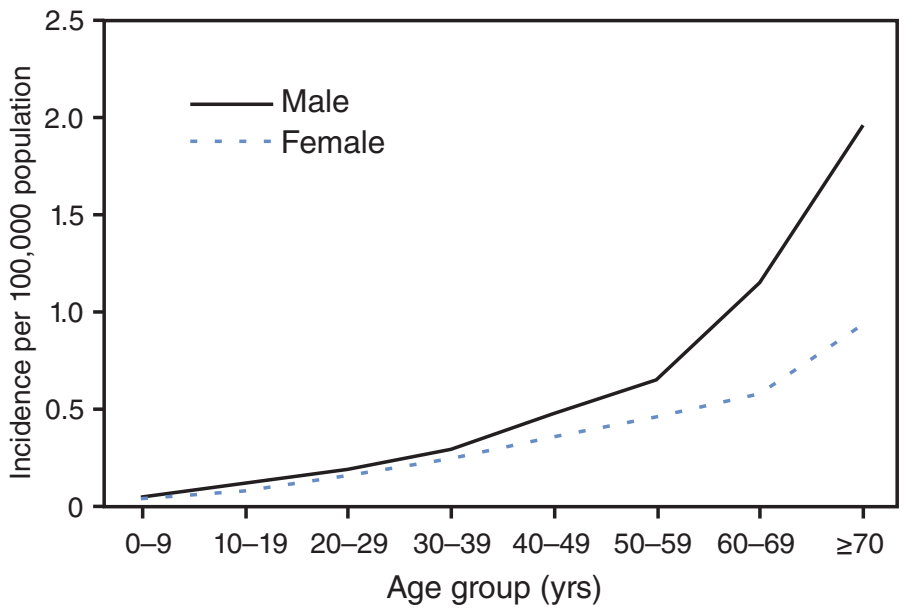

* Calculated using U.S. Census Bureau population estimates for July 1, 2004. 
TABLE 1. West Nile virus neuroinvasive and nonneuroinvasive disease cases and deaths, by year — United States, ${ }^{\star} 1999-2008$

\begin{tabular}{|c|c|c|c|c|c|c|c|c|c|}
\hline \multirow[b]{3}{*}{ Year } & \multicolumn{3}{|c|}{ Neuroinvasive } & \multicolumn{3}{|c|}{ Nonneuroinvasive } & \multicolumn{3}{|c|}{ Total } \\
\hline & \multirow[b]{2}{*}{ No. of cases } & \multicolumn{2}{|c|}{ Deaths } & \multirow[b]{2}{*}{ No. of cases } & \multicolumn{2}{|c|}{ Deaths } & \multirow[b]{2}{*}{ No. of cases } & \multicolumn{2}{|c|}{ Deaths } \\
\hline & & No. & (\%) & & No. & (\%) & & No. & (\%) \\
\hline 1999 & 59 & 7 & (12) & 3 & 0 & (0) & 62 & 7 & (11) \\
\hline 2000 & 19 & 2 & (11) & 2 & 0 & (0) & 21 & 2 & (10) \\
\hline 2001 & 64 & 10 & (16) & 2 & 0 & (0) & 66 & 10 & (15) \\
\hline 2002 & 2,946 & 278 & (9) & 1,210 & 9 & $(<1)$ & 4,156 & 287 & (7) \\
\hline 2003 & 2,866 & 232 & (8) & 6,996 & 32 & $(<1)$ & 9,862 & 264 & (3) \\
\hline 2004 & 1,148 & 94 & (8) & 1,391 & 6 & $(<1)$ & 2,539 & 100 & (4) \\
\hline 2005 & 1,309 & 104 & (8) & 1,691 & 15 & $(<1)$ & 3,000 & 119 & (4) \\
\hline 2006 & 1,495 & 162 & (11) & 2,774 & 15 & $(<1)$ & 4,269 & 177 & (4) \\
\hline 2007 & 1,227 & 117 & (10) & 2,403 & 7 & $(<1)$ & 3,630 & 124 & (3) \\
\hline 2008 & 689 & 41 & (6) & 667 & 3 & $(<1)$ & 1,356 & 44 & (4) \\
\hline Total & 11,822 & 1,045 & (9) & 17,139 & 86 & $(<1)$ & 28,961 & 1,134 & (4) \\
\hline
\end{tabular}

* No cases were reported from Alaska, Hawaii, Maine, or any U.S. territories.

TABLE 2. Number of confirmed and probable cases of West Nile virus neuroinvasive and nonneuroinvasive disease, by year United States, 1999-2008

\begin{tabular}{|c|c|c|c|c|c|c|}
\hline \multirow[b]{2}{*}{ Year } & \multicolumn{2}{|c|}{ Neuroinvasive $(n=11,822)$} & \multicolumn{2}{|c|}{ Nonneuroinvasive $(n=17,139)$} & \multicolumn{2}{|c|}{ Total $(\mathrm{N}=\mathbf{2 8}, 961)$} \\
\hline & Confirmed & Probable & Confirmed & Probable & Confirmed & Probable \\
\hline 1999 & 59 & 0 & 3 & 0 & 62 & 0 \\
\hline 2000 & 19 & 0 & 2 & 0 & 21 & 0 \\
\hline 2001 & 44 & 20 & 1 & 1 & 45 & 21 \\
\hline 2002 & 1,856 & 1,090 & 403 & 807 & 2,259 & 1,897 \\
\hline 2003 & 1,525 & 1,341 & 1,210 & 5,786 & 2,735 & 7,127 \\
\hline 2004 & 532 & 616 & 352 & 1,039 & 884 & 1,655 \\
\hline 2005 & 706 & 603 & 358 & 1,333 & 1,064 & 1,936 \\
\hline 2006 & 1,048 & 447 & 1,391 & 1,383 & 2,439 & 1,830 \\
\hline 2007 & 895 & 332 & 997 & 1406 & 1,892 & 1,738 \\
\hline 2008 & 557 & 132 & 305 & 362 & 862 & 494 \\
\hline Total (\%) & $7,241(61)$ & $4,581(39)$ & $5,022(29)$ & $12,117(71)$ & $12,263(42)$ & $16,698(58)$ \\
\hline
\end{tabular}


TABLE 3. Demographic characteristics of persons with West Nile virus neuroinvasive and nonneuroinvasive disease United States, 1999-2008

\begin{tabular}{|c|c|c|c|c|}
\hline \multirow[b]{2}{*}{ Characteristic } & \multicolumn{2}{|c|}{$\begin{array}{c}\text { Nonneuroinvasive } \\
(\mathrm{N}=17,139)\end{array}$} & \multicolumn{2}{|c|}{$\begin{array}{c}\text { Neuroinvasive } \\
(\mathrm{N}=11,822)\end{array}$} \\
\hline & No. & $(\%)^{*}$ & No. & (\%) \\
\hline \multicolumn{5}{|l|}{ Sex } \\
\hline Male & 8,972 & (52) & 6,887 & (58) \\
\hline Female & 8,124 & (47) & 4,905 & (41) \\
\hline Unknown & 43 & $(<1)$ & 30 & $(<1)$ \\
\hline \multicolumn{5}{|l|}{ Age } \\
\hline Median age (range) & \multirow{2}{*}{\multicolumn{2}{|c|}{47 yrs (1 mo-97 yrs) }} & \multicolumn{2}{|c|}{57 yrs (1 mo-99 yrs) } \\
\hline Age group, yrs & & & & \\
\hline $0-9$ & 237 & (1) & 179 & (2) \\
\hline $10-19$ & 1,130 & (7) & 410 & (3) \\
\hline $20-29$ & 1,423 & (8) & 707 & (6) \\
\hline 30-39 & 2,627 & (15) & 1,120 & (9) \\
\hline $40-49$ & 4,150 & (24) & 1,884 & (16) \\
\hline 50-59 & 3,608 & (21) & 1,995 & (17) \\
\hline $60-69$ & 1,969 & (12) & 1,925 & (16) \\
\hline$\geq 70$ & 1,812 & (11) & 3,549 & (30) \\
\hline Unknown & 183 & (1) & 53 & $(<1)$ \\
\hline \multicolumn{5}{|l|}{ Race } \\
\hline White & 10,743 & (63) & 5,875 & $(50)$ \\
\hline Black & 194 & (1) & 611 & (5) \\
\hline $\begin{array}{l}\text { Native American or } \\
\text { Alaskan Native }\end{array}$ & 287 & (2) & 163 & (1) \\
\hline $\begin{array}{l}\text { Asian or Pacific } \\
\text { Islander }\end{array}$ & 64 & $(<1)$ & 41 & $(<1)$ \\
\hline Unknown & 5,851 & (34) & 5,132 & $(43)$ \\
\hline \multicolumn{5}{|l|}{ Ethnicity } \\
\hline Hispanic & 927 & (5) & 986 & (8) \\
\hline Non-Hispanic & 8,574 & (50) & 4,591 & (39) \\
\hline Unknown & 7,638 & (45) & 6,245 & (53) \\
\hline
\end{tabular}

* Percentage might not equal 100 because of rounding. 
TABLE 4. Demographic characteristics of persons with West Nile virus neuroinvasive disease, by clinical syndrome - United States, 1999-2008

\begin{tabular}{|c|c|c|c|c|c|c|c|c|}
\hline \multirow[b]{2}{*}{ Characteristic } & \multicolumn{2}{|c|}{$\begin{array}{c}\text { Encephalitis } \\
(\mathrm{N}=7,502)\end{array}$} & \multicolumn{2}{|c|}{$\begin{array}{l}\text { Meningitis } \\
(\mathrm{N}=3,930) \\
\end{array}$} & \multicolumn{2}{|c|}{$\begin{array}{l}\text { Acute flaccid paralysis } \\
(\mathrm{N}=311)\end{array}$} & \multicolumn{2}{|c|}{$\begin{array}{c}\text { Unspecified } \\
(\mathrm{N}=79)\end{array}$} \\
\hline & No. & $(\%)$ & No. & $(\%)$ & No. & $(\%)$ & No. & $(\%)$ \\
\hline \multicolumn{9}{|l|}{ Age } \\
\hline Median age (range) & 60 & (1 mo-99 yrs) & 46 & (1 mo-95 yrs) & 55 & (1-94 yrs) & 63 & (5-90 yrs) \\
\hline \multicolumn{9}{|l|}{ Age group, yrs } \\
\hline 0-9 & 98 & (1) & 73 & (2) & 7 & (2) & 1 & (1) \\
\hline $10-19$ & 188 & (3) & 214 & (6) & 5 & (2) & 3 & (4) \\
\hline $20-29$ & 307 & (4) & 386 & (10) & 13 & (4) & 1 & (1) \\
\hline $30-39$ & 479 & (6) & 609 & (15) & 27 & (9) & 5 & (6) \\
\hline $40-49$ & 952 & (13) & 873 & (22) & 54 & (17) & 5 & (6) \\
\hline $50-59$ & 1,188 & (16) & 718 & (18) & 77 & (25) & 12 & (15) \\
\hline $60-69$ & 1,378 & (18) & 479 & (12) & 55 & (18) & 13 & (17) \\
\hline$\geq 70$ & 2,890 & (38) & 554 & (14) & 67 & (22) & 38 & (48) \\
\hline Unknown & 22 & $(<1)$ & 24 & (1) & 6 & (2) & 1 & (1) \\
\hline \multicolumn{9}{|l|}{ Sex } \\
\hline Male & 4,475 & $(60)$ & 2,175 & (55) & 192 & (62) & 45 & $(57)$ \\
\hline Female & 3,007 & $(40)$ & 1,746 & $(44)$ & 119 & (38) & 33 & (42) \\
\hline Unknown & 20 & $(<1)$ & 9 & $(<1)$ & 0 & (0) & 1 & (1) \\
\hline \multicolumn{9}{|l|}{ Race } \\
\hline White & 3,425 & $(46)$ & 2,225 & $(57)$ & 225 & $(72)$ & 0 & (0) \\
\hline Black & 439 & (6) & 149 & (4) & 23 & $(7)$ & 0 & (0) \\
\hline Native American or Alaskan Native & 88 & (1) & 70 & (2) & 5 & (2) & 0 & (0) \\
\hline Asian or Pacific Islander & 12 & $(<1)$ & 28 & (1) & 1 & $(<1)$ & 0 & (0) \\
\hline Unknown & 3,538 & (47) & 1,458 & (37) & 57 & (18) & 79 & $(100)$ \\
\hline \multicolumn{9}{|l|}{ Ethnicity } \\
\hline Hispanic & 425 & (6) & 523 & (13) & 38 & (12) & 0 & $(0.0)$ \\
\hline Non-Hispanic & 2,666 & (35) & 1,730 & (44) & 195 & (63) & 0 & $(0.0)$ \\
\hline Unknown & 4,411 & (59) & 1,677 & (43) & 78 & (25) & 79 & $(100)$ \\
\hline
\end{tabular}


TABLE 5. Annual incidence ${ }^{\star}$ per 100,000 population of West Nile virus neuroinvasive disease, by year and state - United States, 1999-2008

\begin{tabular}{|c|c|c|c|c|c|c|c|c|c|c|c|}
\hline \multirow[b]{2}{*}{ Area/State } & \multicolumn{10}{|c|}{ Year } & \multirow{2}{*}{$\begin{array}{c}\text { Average } \\
\text { 1999-2008 }\end{array}$} \\
\hline & 1999 & 2000 & 2001 & 2002 & 2003 & 2004 & 2005 & 2006 & 2007 & 2008 & \\
\hline United States & $<0.1$ & $<0.1$ & $<0.1$ & 1.0 & 1.0 & 0.4 & 0.4 & 0.5 & 0.4 & 0.2 & 0.4 \\
\hline New England & $-^{\dagger}$ & - & 0.1 & 0.2 & 0.2 & $<0.1$ & 0.1 & 0.1 & $<0.1$ & $<0.1$ & 0.1 \\
\hline Connecticut & - & - & 0.2 & 0.3 & 0.3 & - & 0.1 & 0.2 & 0.1 & 0.1 & 0.1 \\
\hline Maine & - & - & - & - & - & - & - & - & - & - & - \\
\hline Massachusetts & - & - & $<0.1$ & 0.3 & 0.2 & - & 0.1 & $<0.1$ & $<0.1$ & $<0.1$ & 0.1 \\
\hline New Hampshire & - & - & - & - & 0.2 & - & - & - & - & - & $<0.1$ \\
\hline Rhode Island & - & - & - & 0.1 & 0.5 & - & 0.1 & - & - & 0.1 & 0.1 \\
\hline Vermont & - & - & - & - & - & - & - & - & - & - & - \\
\hline Middle Atlantic & 0.1 & $<0.1$ & 0.1 & 0.3 & 0.6 & $<0.1$ & 0.1 & 0.1 & 0.1 & 0.1 & 0.2 \\
\hline New Jersey & - & 0.1 & 0.1 & 0.2 & 0.2 & $<0.1$ & $<0.1$ & $<0.1$ & $<0.1$ & 0.1 & 0.1 \\
\hline New York & 0.3 & 0.1 & 0.1 & 0.4 & 0.3 & $<0.1$ & 0.2 & 0.1 & 0.1 & 0.2 & 0.2 \\
\hline Pennsylvania & - & - & $<0.1$ & 0.3 & 1.2 & 0.1 & 0.1 & 0.1 & $<0.1$ & 0.1 & 0.2 \\
\hline East North Central & - & - & - & 3.6 & 0.3 & 0.1 & 0.6 & 0.5 & 0.2 & 0.1 & 0.5 \\
\hline Illinois & - & - & - & 4.4 & 0.2 & 0.2 & 1.1 & 1.0 & 0.5 & 0.1 & 0.8 \\
\hline Indiana & - & - & - & 2.9 & 0.2 & 0.1 & 0.2 & 0.4 & 0.2 & $<0.1$ & 0.4 \\
\hline Michigan & - & - & - & 5.5 & 0.1 & 0.1 & 0.5 & 0.4 & 0.2 & 0.1 & 0.7 \\
\hline Ohio & - & - & - & 2.7 & 0.7 & 0.1 & 0.4 & 0.3 & 0.1 & 0.1 & 0.4 \\
\hline Wisconsin & - & - & - & 0.4 & 0.1 & 0.1 & 0.2 & 0.2 & 0.1 & 0.1 & 0.1 \\
\hline West North Central & - & - & - & 1.5 & 3.6 & 0.4 & 0.9 & 1.1 & 1.2 & 0.3 & 0.9 \\
\hline lowa & - & - & - & 0.9 & 2.8 & 0.4 & 0.5 & 0.7 & 0.4 & 0.1 & 0.6 \\
\hline Kansas & - & - & - & 0.8 & 3.3 & 0.7 & 0.6 & 0.6 & 0.5 & 0.5 & 0.7 \\
\hline Minnesota & - & - & - & 0.3 & 1.0 & 0.3 & 0.4 & 0.6 & 0.8 & $<0.1$ & 0.3 \\
\hline Missouri & - & - & - & 2.2 & 0.7 & 0.5 & 0.3 & 0.9 & 1.0 & 0.2 & 0.6 \\
\hline Nebraska & - & - & - & 4.9 & 11.2 & 0.4 & 3.1 & 2.6 & 1.2 & 0.4 & 2.4 \\
\hline North Dakota & - & - & - & 0.5 & 14.9 & 0.3 & 1.9 & 3.1 & 7.7 & 0.3 & 2.9 \\
\hline South Dakota & - & - & - & 2.2 & 19.7 & 0.8 & 4.6 & 4.8 & 6.0 & 1.4 & 4.0 \\
\hline South Atlantic & - & - & $<0.1$ & 0.2 & 0.4 & 0.1 & 0.1 & $<0.1$ & 0.1 & $<0.1$ & 0.1 \\
\hline Delaware & - & - & - & - & 1.5 & - & 0.1 & - & 0.1 & - & 0.2 \\
\hline District of Columbia & - & - & - & 2.4 & 0.5 & 0.2 & 0.5 & - & - & 0.7 & 0.4 \\
\hline Florida & - & - & 0.1 & 0.2 & 0.4 & 0.2 & 0.1 & $<0.1$ & $<0.1$ & $<0.1$ & 0.1 \\
\hline Georgia & - & - & 0.1 & 0.3 & 0.3 & 0.2 & 0.1 & $<0.1$ & 0.2 & $<0.1$ & 0.1 \\
\hline Maryland & - & - & 0.1 & 0.4 & 0.9 & 0.2 & 0.1 & 0.2 & 0.1 & 0.1 & 0.2 \\
\hline North Carolina & - & - & - & $<0.1$ & 0.2 & $<0.1$ & $<0.1$ & $<0.1$ & $<0.1$ & $<0.1$ & $<0.1$ \\
\hline South Carolina & - & - & - & $<0.1$ & 0.1 & - & 0.1 & $<0.1$ & 0.1 & - & $<0.1$ \\
\hline Virginia & - & - & - & 0.2 & 0.3 & 0.1 & - & - & $<0.1$ & - & 0.1 \\
\hline West Virginia & - & - & - & 0.2 & 0.1 & - & - & 0.1 & - & 0.1 & $<0.1$ \\
\hline East South Central & - & - & $<0.1$ & 1.7 & 0.5 & 0.3 & 0.4 & 0.7 & 0.4 & 0.3 & 0.4 \\
\hline Alabama & - & - & $<0.1$ & 0.8 & 0.6 & 0.3 & 0.1 & 0.2 & 0.4 & 0.2 & 0.3 \\
\hline Kentucky & - & - & - & 1.3 & 0.3 & $<0.1$ & 0.1 & 0.1 & 0.1 & 0.1 & 0.2 \\
\hline Mississippi & - & - & - & 5.7 & 1.2 & 1.1 & 1.3 & 3.1 & 1.7 & 0.7 & 1.5 \\
\hline Tennessee & - & - & - & 0.8 & 0.4 & 0.2 & 0.3 & 0.3 & 0.1 & 0.2 & 0.2 \\
\hline West South Central & - & - & $<0.1$ & 1.4 & 1.9 & 0.7 & 0.8 & 1.1 & 0.8 & 0.2 & 0.7 \\
\hline Arkansas & - & - & - & 1.2 & 0.8 & 0.6 & 0.5 & 0.9 & 0.5 & 0.2 & 0.5 \\
\hline Louisiana & - & - & $<0.1$ & 4.6 & 2.3 & 1.9 & 2.6 & 2.1 & 0.6 & 0.4 & 1.4 \\
\hline Oklahoma & - & - & - & 0.5 & 1.6 & 0.5 & 0.5 & 0.8 & 1.6 & 0.1 & 0.6 \\
\hline Texas & - & - & - & 0.9 & 2.0 & 0.5 & 0.6 & 1.0 & 0.7 & 0.2 & 0.6 \\
\hline Mountain & - & - & - & $<0.1$ & 4.5 & 1.6 & 0.7 & 1.9 & 1.4 & 0.5 & 1.1 \\
\hline Arizona & - & - & - & - & 0.1 & 3.7 & 0.9 & 1.1 & 0.8 & 1.0 & 0.8 \\
\hline Colorado & - & - & - & 0.1 & 13.7 & 0.9 & 0.5 & 1.4 & 2.0 & 0.3 & 1.9 \\
\hline Idaho & - & - & - & - & - & 0.1 & 0.2 & 9.5 & 0.7 & 0.3 & 1.1 \\
\hline Montana & - & - & - & 0.2 & 8.2 & 0.2 & 0.9 & 1.3 & 3.9 & - & 1.5 \\
\hline Nevada & - & - & - & - & 0.1 & 1.1 & 0.6 & 1.4 & 0.1 & 0.3 & 0.4 \\
\hline New Mexico & - & - & - & - & 4.0 & 1.7 & 1.0 & 0.2 & 2.0 & 0.3 & 0.9 \\
\hline Utah & - & - & - & - & - & 0.2 & 0.8 & 2.2 & 1.0 & 0.2 & 0.5 \\
\hline Wyoming & - & - & - & - & 18.4 & 0.4 & 1.2 & 2.9 & 4.4 & - & 2.7 \\
\hline Pacific & - & - & - & $<0.1$ & $<0.1$ & 0.6 & 0.6 & 0.2 & 0.3 & 0.6 & 0.2 \\
\hline Alaska & - & - & - & - & - & - & - & - & - & - & - \\
\hline California & - & - & - & $<0.1$ & $<0.1$ & 0.8 & 0.8 & 0.2 & 0.4 & 0.8 & 0.3 \\
\hline Hawaii & - & - & - & - & - & - & - & - & - & - & - \\
\hline Oregon & - & - & - & - & - & - & $<0.1$ & 0.2 & 0.2 & 0.1 & 0.1 \\
\hline Washington & - & - & - & - & - & - & - & - & - & $<0.1$ & $<0.1$ \\
\hline
\end{tabular}

* Calculated using U.S. Census Bureau population estimates for July 1 of each year of the reporting period.

† No cases reported. 
The Morbidity and Mortality Weekly Report (MMWR) Series is prepared by the Centers for Disease Control and Prevention (CDC) and is available free of charge in electronic format. To receive an electronic copy each week, visit MMWR's free subscription page at http://www.cdc.gov/mmwr/mmwrsubscribe.html. Paper copy subscriptions are available through the Superintendent of Documents, U.S. Government Printing Office, Washington, DC 20402; telephone $202-512-1800$

Data presented by the Notifiable Disease Data Team and 122 Cities Mortality Data Team in the weekly $M M W R$ are provisional, based on weekly reports to CDC by state health departments. Address all inquiries about the $M M W R$ Series, including material to be considered for publication, to Editor, $M M W R$ Series, Mailstop E-90, CDC, 1600 Clifton Rd., N.E., Atlanta, GA 30333 or to mmwrq@cdc.gov.

All material in the MMWR Series is in the public domain and may be used and reprinted without permission; citation as to source, however, is appreciated.

Use of trade names and commercial sources is for identification only and does not imply endorsement by the U.S. Department of Health and Human Services.

References to non-CDC sites on the Internet are provided as a service to $M M W R$ readers and do not constitute or imply endorsement of these organizations or their programs by CDC or the U.S. Department of Health and Human Services. CDC is not responsible for the content of these sites. URL addresses listed in $M M W R$ were current as of the date of publication.

¿3U.S. Government Printing Office: 2010-623-026/41235 Region IV ISSN: 1546-0738 